\title{
Pendampingan Pengembangan Kapasitas Usaha Berbasis Klaster Peternak Sapi Kabupaten Magetan
}

\author{
Amiril Mukmin ${ }^{1}$ dan Ertika Fitri L. ${ }^{2}$ \\ Program Studi Peternakan Fakultas Pertanian Universitas Islam Kadiri ${ }^{1,2}$ \\ amirilmukmin@uniska-kediri.ac.id ${ }^{1}$ dan ertika@uniska-kediri.ac.id ${ }^{2}$
}

\begin{abstract}
The facilitation activity for developing the capacity of the Magetan District cattle rancher business group is a mentoring activity carried out by the Faculty of Agriculture of UNISKA Kediri to guard and control the business capacity building program for farmers in Magetan district. This assistance is carried out so that the program can run according to the planned path and achieve the expected goals. Mentoring activities began with a survey to find out the initial conditions of livestock in Magetan district, which began on November 20, 2018. Based on survey data, four training topics were formulated, namely: "The Importance of Groups in Livestock Business" delivered in the first training on December 18, 2018; "Jago Makes Feed, Practical Guide to Alternative Animal Feed Production for Ruminants" was delivered in the second training on January 8, 2019; "Reproduction and Animal Health" was submitted in the third training on January 15, 2019; and "Preparations for Cattle Now and Cooking Processed Animal Husbandry Products" were delivered at the fourth training on February 7, 2019.
\end{abstract}

Keywords: facilitation, developing business, cattle rancher.

\begin{abstract}
Abstrak
Kegiatan pendampingan pengembangan kapasitas usaha klaster peternak sapi kabupaten Magetan adalah kegiatan pendampingan yang dilakukan oleh Fakultas Pertanian UNISKA Kediri untuk mengawal dan mengontrol program peningkatan kapasitas usaha bagi para peternak di kabupaten Magetan. Pendampingan ini dilaksanakan agar program dapat berjalan sesuai alur yang direncanakan dan mencapai tujuan yang diharapkan. Kegiatan pendampingan dimulai dari survey untuk mengetahui kondisi awal peternakan di kabupaten Magetan yang dilaksanakan mulai tanggal 20 November 2018. Berdasarkan data hasil survey, dirumuskan 4 materi pelatihan yaitu: "Pentingnya Berkelompok Dalam Usaha Peternakan" disampaikan dalam pelatihan pertama pada tanggal 18 Desember 2018; "Jago Bikin Pakan, Panduan Praktis Pembuatan Pakan Ternak Alternatif Untuk Ruminansia" disampaikan pada pelatihan kedua pada tanggal 8 Januari 2019; "Reproduksi dan Kesehatan Ternak" disampaikan pada pelatihan ketiga pada tanggal 15 Januari 2019; dan "Olahan Produk Peternakan Zaman Now dan Cooking Demo Olahan Sapi” disampaikan pada pelatihan keempat pada tanggal 7 Pebruari 2019.
\end{abstract}

Kata Kunci: pendampingan, pengembangan usaha, peternak sapi. 


\section{Pendahuluan}

PT. Permodalan Nasional Madani (Persero) atau PNM, adalah salah satu Badan Usaha Milik Negara (BUMN) Indonesia yang didirikan sebagai bagian dari solusi strategis pemerintah untuk meningkatkan kesejahteraan masyarakat dan pemerataan ekonomi masyarakat melalui pengembangan akses permodalan dan program peningkatan kapasitas bagi para pelaku Usaha Mikro, Kecil, Menengah, dan Koperasi (UMKMK). PNM meiliki visi yaitu menjadi lembaga pembiayaan terkemuka dalam meningkatkan nilai tambah secara berkelanjutan bagi UMKMK. Sedangkan misi PNM adalah: 1.Meningkatkan kelayakan usaha dan kemampuan bagi wirausaha UMKMK; 2.Meningkatkan akses pembiayaan bagi UMKMK kepada lembaga keuangan baik bank maupun nonbank dalam rangka memperluas lapangan pekerjaan dan dapat meningkatkan kesejahteraan masyarakat; dan 3.Meningkatkan kreativitas dan produktivitas karyawan untuk mencapai kinerja terbaik dalam mengembangkan UMKMK.

PNM Cabang Madiun adalah salah satu cabang PNM yang banyak membiayai permodalan untuk bidang kegiatan usaha peternakan, khususnya peternak sapi di wilayah Magetan. Tidak dipungkiri lagi bahwa sektor peternakan memiliki peran yang strategis tidak saja sebagai sumber pendapatan masyarakat dan menjadi sumber devisa negara, akan tetapi juga mendukung peningkatan kualitas sumber daya manusia melalui penyedia sumber makanan bergizi, sehingga dapat mewujudkan masyarakat yang sehat dan produktif, seperti yang dicita-citakan dalam visi dan misi pembangunan peternakan. Secara umum peternakan rakyat di Indonesia masih berskala kecil dan menerapkan manejemen yang belum efisien, maka dirasa perlu untuk melakukan kegiatan pendampingan peningkatan kapasitas usaha berbasis klaster peternak sapi kabupaten Magetan.

Menurut Sodiq \& Budiono (2012) bahwa pemeliharaan sapi potong pada kelompok tani ternak di pedesaan ditujukan untuk menghasilkan pedet dan bakalan (cow calf operation) serta usaha penggemukan (fattening). Penelitian ini menjadi masukan untuk kegiatan pedampingan ini bahwa masyarakat peternak sapi membutuhkan pendampingan dari pemerintah dan dari pihak akademisi.

Adapun luaran kegiatan yang diharapkan berupa peta klaster peternakan di kabupaten Magetan dan langkah yang perlu dilakukan sehingga secara bertahap akan terjadi peningkatan kuantitas dan kualitas usaha peternakan di kabupaten Magetan. Capaian program memiliki arti yang sangat penting dalam mewujudkan peningkatan kapasitas usaha dengan dukungan lembaga keuangan penyedia modal, termasuk PNM.

Program pengabdian kepada masyarakat ini mempunyai tujuan untuk : 1.Mengidentifikasi permasalahan yang dihadapi oleh peternak melalui kegiatan survey lapangan; 2.Membantu dalam menyelesaikan permasalahan yang dihadapi peternak melalui kegiatan pelatihan; dan 3.Membantu meningkatkan kapasitas usaha dan produktifitas ternak melalui kegiatan pendampingan.

\section{Pelaksanaan Dan Metode}

Untuk mencapai tujuan program yang telah ditetapkan, kegiatan pendampingan ini direncanakan untuk dilaksanakan dalam beberapa kegiatan, yaitu: 1 . Survey kondisi awal calon peserta program; 2. Pelatihan peningkatan produktifitas peternakan; dan 3. Pendampingan peserta program.

Survey kondisi awal calon peserta menggunakan kuesioner pada gambar 1 berikut: 
Survey kondisi awal calon peserta program memiliki sasaran utama. Sasaran utamanya adalah untuk mengidentifikasi permasalahan yang dihadapi oleh para peserta program (peternak sapi di Kabupaten Magetan) melalui sejumlah pertanyaan yang dikemas dalam sebuah kuesioner. Survey ini juga untuk mengetahui kondisi awal dari peserta program sebelum program ini dilakukan, dimana hal ini akan dibandingkan dengan kondisi pasca program, sehingga dapat diketahui ada/tidaknya perkembangan dari peserta program. Data hasil survey dijadikan sebagai patokan untuk menentukan tema apa saja yang akan diangkat dalam kegiatan pelatihan.

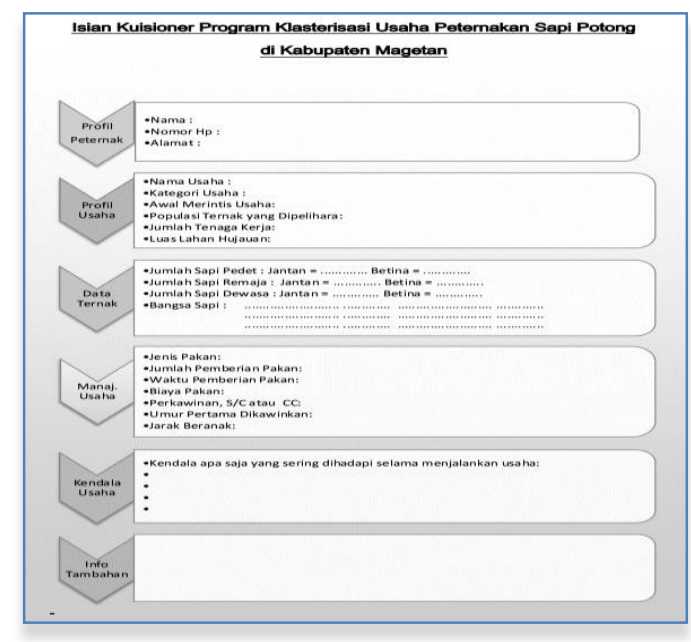

Gambar 1. Kuesioner untuk survey awal program

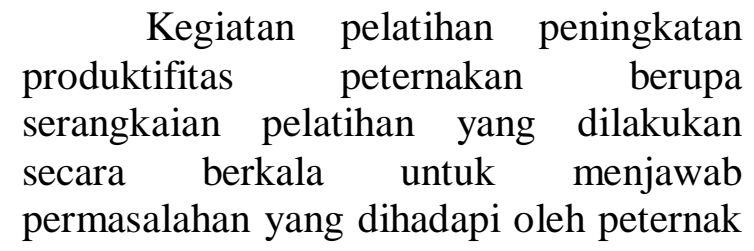

sapi di daerah Magetan. Topik pelatihan disesuaikan dengan kendala yang paling sering dihadapi oleh peternak (berdasarkan hasil survey yang telah dilaksanakan), sehingga diharapkan setelah mengikuti kegiatan pelatihan ini, usaha peternakan yang meraka jalankan tidak lagi menghadapi kendala yang berarti. Kalaupun dari peternak menghadapi permasalahan, mereka sudah memahaminya dan bisa mengambil tindakan yang lebih bijak sehingga tidak terlalu berdampak pada kegiatan usaha yang sedang mereka jalankan.

Pendampingan diberikan kepada peserta program. Kegiatan pendampingan dilakukan untuk mendampingi peternak dalam meningkatkan kapasitas usahanya. Kegiatan pendampingan bisa dilakukan secara langsung formal ataupun informal. Pendampingan secara formal dilaksanakan melalui pertemuan rutin dan survey kepada peternak untuk mengetahui perkembangan usaha yang dilaksanakan. Pendampingan secara formal dimulai sejak kegiatan secara resmi dibuka di awal program sampai kegiatan penutupan di akhir program. Pendampingan secara informal dilaksanakan melalui jaringan komunikasi di media sosial untuk saling berinteraksi bertukar pendapat terkait usaha peternakan yang sedang dilaksanakan. Pendampingan secara informal dimulai sejak kegiatan secara resmi dibuka di awal program sampai tidak terbatas waktu.

Jadwal kegiatan yang direncanakan dalam kegiatan pendampingan peningkatan kapasitas usaha berbasis klaster peternakan sapi kabupaten Magetan adalah sebagaimana terperinci dalam tabel 1 . 
Tabel 1. Jadwal kegiatan yang direncanakan

\begin{tabular}{|c|c|c|c|c|}
\hline No & Kegiatan & Tempat & Waktu & Keterangan \\
\hline 1 & $\begin{array}{l}\text { Survey persiapan } \\
\text { program }\end{array}$ & $\begin{array}{l}\text { Lokasi } \\
\text { peternakan }\end{array}$ & $\begin{array}{l}19 \text { November } \\
2018-08 \\
\text { Desember } \\
2018\end{array}$ & $\begin{array}{l}\text { Petugas survey mendatangi } \\
\text { mendatangi beberapa peternak } \\
\text { sebagai sampel }\end{array}$ \\
\hline 2 & $\begin{array}{l}\text { Analisa data } \\
\text { hasil survey }\end{array}$ & $\begin{array}{l}\text { Kampus } \\
\text { UNISKA } \\
\text { Kediri }\end{array}$ & $\begin{array}{l}10 \text { Desember } \\
2018-22 \\
\text { Desember } \\
2018\end{array}$ & $\begin{array}{l}\text { Hasil survey dianalisa untuk } \\
\text { menentukan topik, sasaran } \\
\text { peternak dan lokasi pelatihan }\end{array}$ \\
\hline 3 & $\begin{array}{l}\text { Pembukaan, } \\
\text { Sosialisasi dan } \\
\text { motivasi } \\
\text { kewirausahaan }\end{array}$ & $\begin{array}{l}\text { Kantor } \\
\text { PNM } \\
\text { Magetan } \\
\text { (tentative) }\end{array}$ & $\begin{array}{l}27 \text { Desember } \\
2018\end{array}$ & $\begin{array}{l}\text { Menghadirkan semua peternak } \\
\text { yang disurvey untuk } \\
\text { menyampaikan hasil survey dan } \\
\text { rencana pelatihan yang akan } \\
\text { dilaksanakan }\end{array}$ \\
\hline 4 & $\begin{array}{l}\text { Pelatihan } \\
\text { pertama }\end{array}$ & (tentative) & $\begin{array}{l}\text { 02 Januari } \\
2019\end{array}$ & Topik $1 \& 2$ \\
\hline 5 & Pelatihan kedua & (tentative) & $\begin{array}{l}16 \text { Januari } \\
2019\end{array}$ & Topik 3 \\
\hline 6 & Pelatihan ketiga & (tentative) & $\begin{array}{l}17 \text { Januari } \\
2019\end{array}$ & Topik 4 \\
\hline 7 & $\begin{array}{l}\text { Penutupan } \\
\text { program }\end{array}$ & (tentative) & $\begin{array}{l}14 \text { Pebruari } \\
2019\end{array}$ & $\begin{array}{l}\text { Menghadirkan semua peternak } \\
\text { yang yang telah mengikuti } \\
\text { pelatihan untuk dilakukan } \\
\text { penutupan program }\end{array}$ \\
\hline
\end{tabular}

(Sumber: PNM,2019)

\section{Hasil Dan Pembahasan}

Program peningkatan kapasitas usaha berbasis klaster peternakan sapi kabupaten Magetan dilaksanakan atas kerjasama dari 3 tim, yaitu tim 1 (PNM Cabang Madiun), tim 2 (Ayo Start Madiun), dan tim 3 (Fakultas Pertanian UNISKA Kediri). Ketiga tim ini berkolaborasi menyelenggakan program mulai dari survey awal program, analisa data hasil survey, pembukaan program, pelatihan-pelatihan, dan pendampingan. Hasil dari kegiatan ini terdiri dari: 1. Survey awal program, 2. Analisa data hasil survey dan sebar kuesioner; 3. Hasil sebar kuesioner

Survey awal kegiatan program ini dilakukan untuk mendapatkan informasi terkait kondisi peternakan di wilayah kabupaten Magetan. Kegiatan survey yang dilakukan pada nasabah PNM yang memiliki kegiatan usaha berupa peternakan. Untuk mendapatkan data sasaran survey yang tepat, petugas survey berkoordinasi dengan PNM cabang Madiun yang sudah memiliki data nasabah-nasabah yang berprofesi sebagai seorang peternak, baik usahanya sebagai usaha utama ataupun hanya sebagai usaha sampingan.

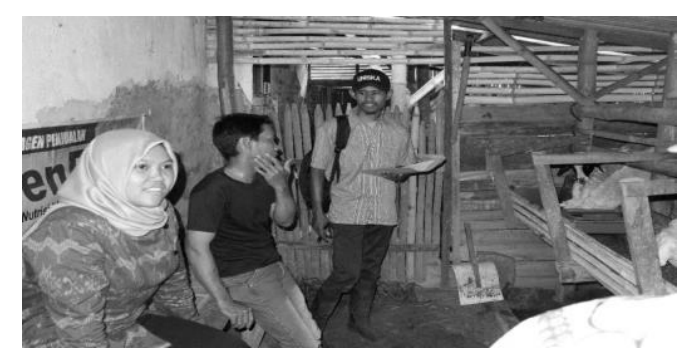

Gambar 2. Survey ke peternak, usaha budidaya domba dan penggemukan sapi. 
Menurut data yang diterima, ada sekitar 30 orang peternak sebagai sasaran survey. Namun, karena terkendala waktu dan tenaga, kegiatan survey dilakukan secara sampling sebesar $10 \%$ dari total sasaran survey untuk dijadikan sebagai rujukan awal dalam merancang topik pelatihan dan pendampingan. Kegiatan survey dilakukan pada 3 orang peternak di wilayah Magetan khususnya Plaosan dengan didampingi oleh tim dari PNM yang membantu memediasi pelaksanaan survey. Dalam kegiatan survey, petugas survey mengajukan beberapa pertanyaan untuk menggali informasi guna menggam-barkan kondisi peternakan dan strategi usaha yang dilakukan oleh peternak.

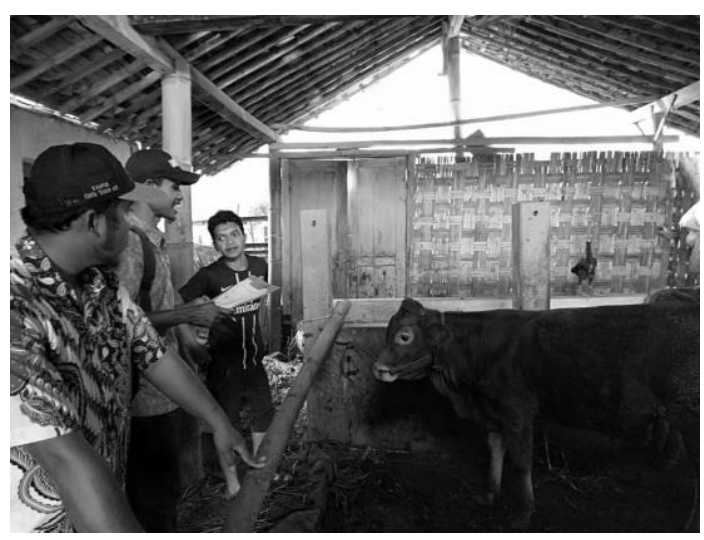

Gambar 3. Survey ke peternak, usaha pembesaran sampai penggemukan sapi potong.

Disadari bahwa kegiatan survey tidak mampu menjangkau semua peternak di wilayah Magetan, maka untuk melengkapi data hasil survey awal ini dilakukan sebar kuesioner kepada seluruh peserta yang hadir pada acara kegiatan pembukaan program. Harapannya akan dapat diketahui kondisi peternakan yang dijalankan oleh semua peserta program. Informasi yang digali dari kuesioner dibuat sama seperti pertanyaan-pertanyaan yang diajukan dalam survey ke lapang.

Sebar kuesioner dilakukan di akhir sesi acara pembukaan program. Kuesioner

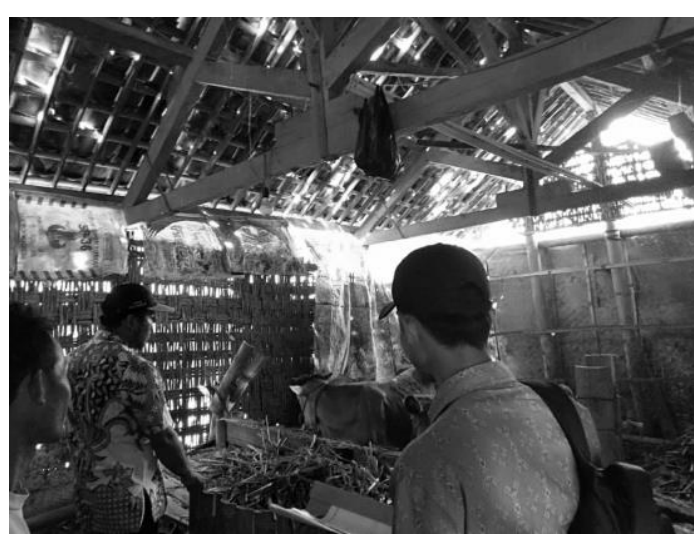

Gambar 4. Survey ke peternak, usaha pembesaran sapi potong.

dibagikan kepada 40 peserta yang hadir untuk diisi berdasarkan informasi kegiatan usaha yang dilakukan oleh masing-masing peserta. Setelah selesai diisi, lembar kuesioner langsung dikembalikan kepada panitia untuk diolah sebagai data awal kondisi usaha peternakan yang dijalankan oleh peternak di wilayah Magetan.

Berdasarkan hasil survey, diketahui bahwa usaha peternakan yang dilakukan oleh nasabah PNM di wilayah Magetan adalah untuk menghasilkan sapi jantan yang siap potong atau usaha penggemukan, meskipun kalau dicermati lagi kegiatannya tidak murni penggemukan karena bakalan atau bibit yang digunakan memilih sapi yang masih sangat muda (kurang dari 1 tahun) sehingga proses pemeliharaannya membutuhkan waktu yang cukup lama, bisa sampai 1,5 tahun. Untuk usaha penggemukan, idealnya bakalan yang digunakan paling tidak berumur 1,5 tahun dan masa pemeliharaan tidak lebih dari 6 bulan.

Dari segi jumlah kepemilikan hewan ternak, peternak di daerah Magetan termasuk peternak kecil, dengan kepemilikan ternak hanya sekitar 1-2 ekor tiap peternaknya. Perkandangan yang ada masih sangat sederhana. Dengan jumlah kepemilikan ternak yang sedikit, penerapan teknologi untuk mengoptimalkan usaha 
peternakan akan sulit dilakukan. Diakui atau tidak, penerapan teknologi akan memerlukan tambahan biaya investasi, sehingga jika jumlah ternak yang dipelihara hanya sedikit, penerapan teknologi tidak akan ekonomis. Salah satu strategi yang dapat diterapkan adalah melakukan usaha peternakan sapi secara berkelompok supaya populasi ternak yang dipelihara memenuhi batas usaha ekonomis. Pelatihan untuk memotivasi peternak sapi untuk membentuk kelompok dan melakukan usaha bersama perlu dibangun agar mudah diterapkan dan keuntungan yang didapatkan usaha peternakan dapat dioptimalkan. Berdasarkan hasil survey, jenis sapi yang dipelihara peternak untuk dipelihara sebagai penghasil daging adalah sapi limousine dan simental. Dilihat dari potensi genetik, kedua jenis sapi ini sudah sangat sesuai untuk tujuan usaha pemeliharaan ternak disana. Sebagian peternak sapi sudah menggunakan hijauan dan konsentrat sebagai pakan penguat untuk ternaknya, namun kebanyakan peternak sapi di sana masih mengandalkan pakan hijauan saja sebagai pakannya, bahkan ada juga peternak sapi yang hanya mengandalkan hijauan dari hasil merumput di tanah lapang yang kualitasnya bervariasi sehingga sangat berdampak pada ketidakstabilan pertumbuhan ternak.

Tabel 2. Data hasil survey tentang jumlah kepemilikan sapi

\begin{tabular}{cccccc}
\hline No. & $\begin{array}{c}\text { Nama } \\
\text { Peternak }\end{array}$ & Alamat & $\begin{array}{c}\text { Kategori } \\
\text { Usaha }\end{array}$ & Tujuan Usaha & $\begin{array}{c}\text { Jumlah } \\
\text { Sapi }\end{array}$ \\
\hline 1 & Puji Widodo & Plaosan & Sampingan & Penggemukan & 1 ekor \\
\hline 2 & Imam & Plaosan & Sampingan & $\begin{array}{c}\text { Pembesaran }- \\
\text { Penggemukan }\end{array}$ & 2 ekor \\
\hline 3 & Isranto & Plaosan & Sampingan & Pembesaran & 2 ekor \\
\hline
\end{tabular}

(Sumber : PNM, 2019 )

Tabel 3. Data hasil survey tentang pakan dan kendala usaha

\begin{tabular}{cccccl}
\hline No. & $\begin{array}{c}\text { Nama } \\
\text { Peternak }\end{array}$ & Alamat & Jenis Pakan & Luas Lahan & \multicolumn{1}{c}{ Kendala Usaha } \\
\hline 1 & Puji Widodo & Plaosan & $\begin{array}{c}\text { Hijauan dan } \\
\text { konsentrat }\end{array}$ & $\pm 0,05$ ha & $\begin{array}{l}\text { Penentuan harga jual } \\
\text { tergantung blantik }\end{array}$ \\
\hline 2 & Imam & Plaosan & Hijauan & $\pm 0,05$ ha & Masa pemeliharaan lama \\
\hline 3 & Isranto & Plaosan & Hijauan & - & $\begin{array}{l}\text { Ternak sering lesu dan } \\
\text { mengalami gangguan } \\
\text { kulit }\end{array}$ \\
\hline
\end{tabular}

(Sumber : PNM, 2019)

Untuk usaha penggemukan sapi secara intensif, penggunaan pakan konsentrat bersifat wajib karena nutrisi yang hanya dicukupi dari pakan hijauan saja tidak akan cukup untuk mendukung pertumbuhan sapi maksimal, apalagi jenis sapi potong seperti jenis limousine dan simental. Kesadaran penggunaan pakan penguat atau pengawetan pakan supaya kualitas pakan yang dikonsumsi oleh ternak bisa stabil perlu ditumbuhkan melalui kegiatan pelatihan sehingga laju pertumbuhan sapi dapat dimaksimalkan dan kegiatan usaha peternakan yang dijalankan bisa lebih menguntungkan.

Para peternak juga tidak memiliki bangunan khusus untuk memelihara ternak sapinya. Bangunan kandang untuk ternaknya dibuat menyatu dengan bangunan tempat tinggalnya, sehingga 
kebersihan kandang harus benar-benar dijaga. Perkandangan dan penanganan limbah yang belum maksimal dapat memicu beberapa penyakit yang turut mengganggu kesehatan hewan ternak yang dipelihara. Pemahaman terkait penyakit dan cara penanganannya juga perlu dikuasai oleh peternak agar usaha peternakannya dapat lancar tanpa kendala yang berarti.

Dari data hasil survey yang telah diolah, dirumuskan 4 topik sementara yang akan disampaikan dalam rangkain kegiatan pelatihan pengembangan kapasitas usaha bersama PNM. Topik-topik sementara tersebut antara lain adalah: 1. Kelompok ternak dengan judul "Pentingnya Berkelompok Dalam Usaha Peternakan”, 2. Pakan ternak dengan judul "Jago Bikin

Tabel 4. Data hasil kuesioner tentang jumlah kepemilikan sapi

\begin{tabular}{|c|c|c|c|c|c|}
\hline No. & $\begin{array}{c}\text { Nama } \\
\text { Peternak }\end{array}$ & Alamat & $\begin{array}{l}\text { Kategori } \\
\text { Usaha }\end{array}$ & Tujuan Usaha & $\begin{array}{c}\text { Jumlah } \\
\text { Sapi }\end{array}$ \\
\hline 1 & $\begin{array}{l}\text { Bayu } \\
\text { Piyambodo }\end{array}$ & Sidorejo & Utama & $\begin{array}{c}\text { Produksi Susu dan } \\
\text { Pembesaran }\end{array}$ & 12 ekor \\
\hline 2 & $\begin{array}{l}\text { Yuyun } \\
\text { Prastiono }\end{array}$ & Plaosan & Sampingan & $\begin{array}{c}\text { Produksi Susu dan } \\
\text { Pembesara }\end{array}$ & 3 ekor \\
\hline 3 & Budianto & Plaosan & Sampingan & Produksi Susu & 3 ekor \\
\hline 4 & Eko Wahyudi & Plaosan & Utama & $\begin{array}{c}\text { Produksi Susu dan } \\
\text { Pembesaran }\end{array}$ & 10 ekor \\
\hline 5 & Saiful Malik & Karangrejo & Sampingan & Penggemukan & 2 ekor \\
\hline 6 & $\begin{array}{l}\text { Erwin Dwi } \\
\text { Saputra }\end{array}$ & Plaosan & Sampingan & Penggemukan & 3 ekor \\
\hline 7 & $\begin{array}{l}\text { Dandung Dwi } \\
\text { Prasetya }\end{array}$ & Poncol & Utama & $\begin{array}{l}\text { Pembesaran - } \\
\text { Penggemukan }\end{array}$ & 5 ekor \\
\hline 8 & Widi & Grobogan & Utama & $\begin{array}{l}\text { Pembesaran - } \\
\text { Penggemukan }\end{array}$ & 6 ekor \\
\hline 9 & Gatot Suparno & Ngoriboyo & Utama & Pembesaran & 8 ekor \\
\hline 10 & Samsuri & Ngoriboyo & Sampingan & $\begin{array}{l}\text { Pembesaran dan } \\
\text { Penggemukan }\end{array}$ & 4 ekor \\
\hline 11 & $\begin{array}{l}\text { Bambang } \\
\text { Utomo }\end{array}$ & Plaosan & Sampingan & Pembesaran & 2 ekor \\
\hline 12 & $\begin{array}{l}\text { Dwiyan } \\
\text { Budiargo }\end{array}$ & Plaosan & - & - & - \\
\hline 13 & Joko Santosa & Plaosan & Sampingan & Penggemukan & 2 ekor \\
\hline 14 & Muryadi & Plaosan & Sampingan & Penggemukan & 1 ekor \\
\hline 15 & Siti Rumtani & - & - & - & - \\
\hline 16 & $\begin{array}{l}\text { Moedji } \\
\text { Soesanto } \\
\end{array}$ & Kawedanan & Sampingan & Penggemukan & 4 ekor \\
\hline 17 & $\begin{array}{l}\text { Eni } \\
\text { Rusmawati }\end{array}$ & - & - & - & - \\
\hline
\end{tabular}

Pakan, Panduan Praktis Pembuatan Pakan Ternak Alternatif Untuk Ruminansia", 3. Kesehatan ternak dengan judul "Kesehatan Ternak", dan 4. Olahan produk ternak dengan judul "Olahan Produk Peternakan Zaman Now dan Cooking Demo Olahan Sapi”.

Kuesioner yang disebar pada saat acara pembukaan program memberikan informasi tambahan untuk menggambarkan profil kondisi peternakan di kabupaten Magetan. Dari 40 lembar kuesioner yang disebar, didapat 22 kuesioner yang kembali dan terisi. Data rekapitulasi hasil sebar kuesioner tersebut ditampilkan pada tabel 4 dan tabel 5. 


\begin{tabular}{cllccc}
\hline No. & $\begin{array}{c}\text { Nama } \\
\text { Peternak }\end{array}$ & Alamat & $\begin{array}{c}\text { Kategori } \\
\text { Usaha }\end{array}$ & Tujuan Usaha & $\begin{array}{c}\text { Jumlah } \\
\text { Sapi }\end{array}$ \\
\hline 18 & Sulastri & Pacalan & Sampingan & Pembesaran & 2 ekor \\
\hline 19 & Riyanda Theo & Pocol & - & - & - \\
\hline 20 & Budi W. & Plaosan & - & - & - \\
\hline 21 & $\begin{array}{l}\text { Denny } \\
\text { Hermawan }\end{array}$ & Ngawi & - & - & - \\
\hline 22 & Handy & Kediri & - & - & - \\
\hline$($ Sumber : PNM, 2019) & & & &
\end{tabular}

Tabel 5. Data hasil kuesioner tentang pakan dan kendala usaha

\begin{tabular}{|c|c|c|c|c|c|}
\hline No. & $\begin{array}{c}\text { Nama } \\
\text { Peternak }\end{array}$ & Alamat & Jenis Pakan & $\begin{array}{c}\text { Luas } \\
\text { Lahan }\end{array}$ & Kendala Usaha \\
\hline 1 & $\begin{array}{l}\text { Bayu } \\
\text { Piyambodo }\end{array}$ & Sidorejo & $\begin{array}{c}\text { Hijauan dan } \\
\text { konsentrat }\end{array}$ & \pm 1 ha & $\begin{array}{l}\text { Pengolahan limbah } \\
\text { Produksi rendah }\end{array}$ \\
\hline 2 & $\begin{array}{l}\text { Yuyun } \\
\text { Prastiono }\end{array}$ & Plaosan & Hijauan & $\pm 0,2$ ha & - \\
\hline 3 & Budianto & Plaosan & $\begin{array}{l}\text { Hijauan dan } \\
\text { konsentrat }\end{array}$ & $\pm 0,5$ ha & $\begin{array}{l}\text { Permodalan, } \\
\text { Gangguang reproduksi } \\
\text { Pengolahan susu }\end{array}$ \\
\hline 4 & $\begin{array}{l}\text { Eko } \\
\text { Wahyudi } \\
\end{array}$ & Plaosan & $\begin{array}{c}\text { Hijauan dan } \\
\text { konsentrat }\end{array}$ & \pm 1 ha & $\begin{array}{l}\text { Kawin berulang, } \\
\text { Sering diare }\end{array}$ \\
\hline 5 & Saiful Malik & Karangrejo & Hijauan & - & $\begin{array}{l}\text { Ketersediaan pakan, } \\
\text { Kesehatan, } \\
\text { Pemasaran }\end{array}$ \\
\hline 6 & $\begin{array}{l}\text { Erwin Dwi } \\
\text { Saputra }\end{array}$ & Plaosan & - & - & - \\
\hline 7 & $\begin{array}{l}\text { Dandung } \\
\text { Dwi } \\
\text { Prasetya }\end{array}$ & Poncol & $\begin{array}{l}\text { Hijauan dan } \\
\text { konsentrat }\end{array}$ & - & $\begin{array}{l}\text { Masa pemeliharaan lama, } \\
\text { Nafsu makan sapi rendah }\end{array}$ \\
\hline 8 & Widi & Grobogan & Hijauan & $\pm 0,5$ ha & $\begin{array}{l}\text { Pemasaran, } \\
\text { Pakan, } \\
\text { Pencatatan }\end{array}$ \\
\hline 9 & $\begin{array}{l}\text { Gatot } \\
\text { Suparno }\end{array}$ & Ngoriboyo & Pakan lengkap & - & - \\
\hline 10 & Samsuri & Ngoriboyo & Pakan lengkap & - & - \\
\hline 11 & $\begin{array}{l}\text { Bambang } \\
\text { Utomo }\end{array}$ & Plaosan & $\begin{array}{c}\text { Hijauan dan } \\
\text { konsentrat }\end{array}$ & - & $\begin{array}{l}\text { Pakan, } \\
\text { Pemasaran }\end{array}$ \\
\hline 12 & $\begin{array}{l}\text { Dwiyan } \\
\text { Budiargo }\end{array}$ & Plaosan & - & - & - \\
\hline 13 & Joko Santosa & Plaosan & Hijauan & - & Permodalan \\
\hline 14 & Muryadi & Plaosan & Hijauan & - & Permodalan \\
\hline 15 & Siti Rumtani & - & - & - & $\begin{array}{l}\text { Belum beternak, } \\
\text { Masih belajar }\end{array}$ \\
\hline 16 & $\begin{array}{l}\text { Moedji } \\
\text { Soesanto }\end{array}$ & Kawedanan & $\begin{array}{c}\begin{array}{c}\text { Hijauan dan } \\
\text { konsentrat }\end{array} \\
\end{array}$ & $\pm 0,42$ ha & $\begin{array}{l}\text { Kendala pakan } \\
\text { Pertumbuhan lambat }\end{array}$ \\
\hline 17 & $\begin{array}{l}\text { Eni } \\
\text { Rusmawati }\end{array}$ & - & - & - & - \\
\hline 18 & Sulastri & Pacalan & Hijauan & - & Sering kembung \\
\hline 19 & $\begin{array}{l}\text { Riyanda } \\
\text { Theo }\end{array}$ & Pocol & - & - & - \\
\hline
\end{tabular}




\begin{tabular}{clcccl}
\hline No. & $\begin{array}{c}\text { Nama } \\
\text { Peternak }\end{array}$ & Alamat & Jenis Pakan & $\begin{array}{c}\text { Luas } \\
\text { Lahan }\end{array}$ & \multicolumn{1}{c}{ Kendala Usaha } \\
\hline 20 & Budi W. & Plaosan & - & - & - \\
\hline 21 & $\begin{array}{l}\text { Denny } \\
\text { Hermawan }\end{array}$ & Ngawi & - & - & $\begin{array}{l}\text { Belum beternak, } \\
\text { Masih belajar }\end{array}$ \\
\hline 22 & Handy & Kediri & - & - & $\begin{array}{l}\text { Belum beternak, } \\
\text { Masih belajar }\end{array}$ \\
\hline
\end{tabular}

(Sumber: PNM, 2019)

Dari data hasil sebar kuesioner tersebut, terkait dengan kepemilikan ternak, diketahui ternyata beberapa peternak ada yang menggeluti bidang memelihara sapi perah betina untuk diambil susunya. Jumlah kepemilikan ternak sapi perah tiap peternaknya relatif lebih tinggi dibandingkan dengan kepemilikan ternak sapi potong. Untuk peternak sapi perah, jumlah kepemilikan ternak antara 3-12 ekor, dengan rata-rata kepemilikan 7 ekor sedangkang untuk peternak sapi potong jumlah kepemilikan ternak antara 1-8 ekor dengan rata-rata kepemilikan 3,5 ekor.

Peternak sapi perah cenderung sudah menerapkan tatalaksana yang lebih tertib dibandingkan dengan peternak sapi potong. Namun demikian, pada usaha pemeliharaan sapi perah muncul kendala reproduksi seperti perkawinan berulang dan jarak beranak yang jauh. Pencatatan reproduksi juga kurang tertib sehingga menyulitkan mengurai permasalahan untuk mendapatkan solusi yang tepat.

Terkait dengan penyediaan pakan, peternak sapi perah sudah memperhatikan kebutuhan nutrisi ternaknya lebih baik dibandingkan peternak sapi potong. Para peternak sapi perah menggunakan konsentrat untuk mendukung produksi susu sapi perahnya sedangkan peternak sapi potong masih banyak yang hanya mengandalkan hijauan sebagai pakan tunggalnya. Lebih dari itu, dalam menyediakan hijauan kebanyakan peternak sapi perah sudah menyediakan lahan khusus untuk produksi hijauan, sedangkan sebagian besar peternak sapi potong tidak memiliki lahan khusus untuk produksi hijauan.

Kondisi lingkungan di daerah Magetan yang tidak jauh berbeda dengan daerah di Indonesia yang lain, yaitu beriklim tropis yang menyebabkan ketersediaan hijauan tidak stabil, khususnya antara musim penghujan dengan musim kemarau. Ketika musim penghujan, hijauan tumbuh subur dan ketersediaannya berlimpah namun ketika musim kemarau pertumbuhan hijauan terganggu dan ketersediannya cukup langka. Kondisi ini perlu disikapi dengan pengawetan hijauan supaya ketersediaan hijauan dapat dipertahankan sepanjang tahun.

Informasi-informasi tambahan dari hasil sebar kuesioner ini menjadi dasar untuk menambah topik baru terkait dengan reproduksi yang digabung dengan topik ketiga yaitu tentang kesehatan ternak sehingga judulnya ditambah menjadi "Reproduksi dan Kesehatan Ternak".

Berdasarkan semua informasi yang diperoleh (dari survey langsung dan sebar kuesioner), ditetapkan 4 topik pelatihan yang akan dilaksanakan, yaitu: 1.Pelatihan pertama dengan judul "Pentingnya Berkelompok Dalam Usaha Peternakan", 2.Pelatihan kedua dengan judul "Jago Bikin Pakan, Panduan Praktis Pembuatan Pakan Ternak Alternatif Untuk Ruminansia", 3.Pelatihan ketiga dengan judul "Reproduksi dan Kesehatan Ternak", dan 4.Pelatihan keempat dengan judul "Olahan Produk Peternakan Zaman Now dan Cooking Demo Olahan Sapi”. Semua kegiatan pelatihan ini akan diselenggarakan 
di ruang pertemuan Putra Nirwana, Plaosan-Magetan.

Acara pembukaan program, awalnya direncanakan pada tanggal 27 Desember 2018. Akan tetapi, karena persiapan program yang berupa survey awal dan analisa data dapat berjalan cukup lancar, maka pembukaan program dilaksanakan lebih awal, yaitu

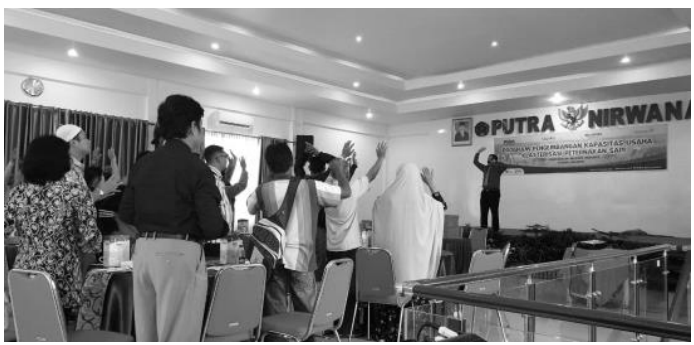

Gambar 6. Peserta program mengikuti instruksi dari motivator.

dilaksanakan pada hari Selasa, 18 Desember 2019 di ruang pertemuan Putra Nirwana, Plaosan-Magetan. Acara pembukaan ini dihadiri oleh sekitar 60 peserta. Mayoritas peserta adalah peternak, namun beberapa yang lain ada juga yang belum sebagai peternak tetapi memiliki keinginan akan melakukan usaha beternak sehingga mereka justru sengaja hadir untuk serius belajar untuk memulai usaha beternak. Peserta yang mengikuti program tidak hanya dibatasi nasabah PNM saja, karena diakui ternyata masih banyak masyarakat yang belum mengenal PNM ini. Untuk peserta nan nasabah, harapannya mereka akan mengetahui kiprah PNM dalam mendukung usaha masyarakan sehingga kedepannya mereka akan bergabung menjadi nasabah.

Kegiatan program pendampingan ini secara resmi dibuka oleh Ibu Erni Margayanti selaku Kabag PKU Pusat, yang secara khusus dating dari Jakarta untuk menghadiri acara pembukaan ini. Beliau menjelaskan terkait tujuan dan sasaran dari program yang dilaksanakan melalui beberapa kegiatan termasuk diantaranya adalah pelatihan-pelatihan yang dilakukan secara berkala. Beliau berharap semua peserta yang hadir diacara pembukaan ini akan dapat mengikuti semua rangkaian pelatihan yang telah direncanakan, supaya hasil yang direncanakan berupa peningkatan kapasitas usaha dapat dicapai secara maksimal.

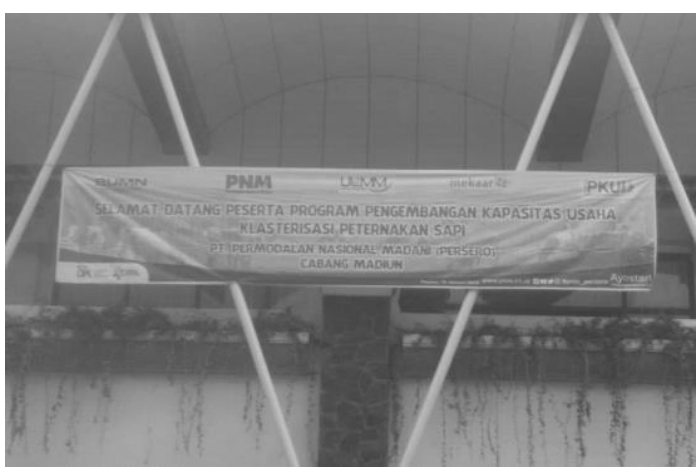

Gambar 5. Spanduk selamat datang untuk semua peserta program yang dipasang di luar gedung pertemuan.

Setelah program secara resmi dibuka, dilanjutkan sambutan dari Bapak Yusbar selaku Kepala Cabang PNM Madiun. Beliau menjelaskan tentang apa itu PNM dan kiprahnya dalam mendukung kegiatan usaha masyarakat, khususnya dalam hal permodalan. Yang intinya, masyarakat yang serius melakukan kegiatan usaha produktif termasuk beternak tidak perlu khawatir lagi terkait permodalan, karena PNM cabang Madiun siap digandeng untuk membantu. Untuk melengkapi kegiatan pembukaan program, Pak Erfan dari Ayo Start memberi motivasi kewirausahaan untuk mendongkrak semangat berwirausaha bagi para peserta program. Beliau menegaskan, untuk menjadi sukses harus diawali dengan keinginan dan tekat. Dan yang paling penting lagi adalah peternak juga boleh dan bisa sukses. 
Pelatihan pertama dari serangkaian program pendampingan peningkapatan kapasitas usaha berbasis klaster peternak sapi di Magetan dilaksanakan pada hari Selasa, 18 Desember 2018. Sesuai rencana awal, pelatihan ini mengangkat topik "Pentingnya Berkelompok Dalam Usaha Peternakan". Penentuan topik ini dilandasi dari hasil survey yang menunjukkan jumlah kepemilikan ternak para peternak di Magetan yang hanya sedikit, sehingga penerapan teknologi tidak akan layak secara ekonomi jika hanya melakukan usaha sendiri-sendiri. Dengan melakukan usaha peternakan secara berkelompok diharapkan peternak akan mudah menerapkan teknologi untuk meningkatkan produktivitas ternaknya. Di sisi lain, kaitannya dengan agribisnis, peternakan bisa mendapatkan posisi tawar yang lebih.

Tujuan utama dari penyampaian

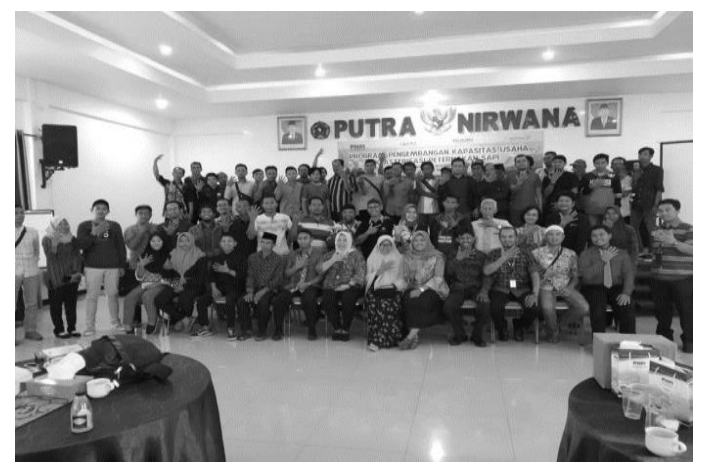

Gambar 7. Foto bersama semua peserta pembukaan program.

materi tentang kelompok ini adalah untuk memotivasi peserta program untuk membentuk atau mengoptimalkan peran kelompok dalam meningkatkan kapasitas usaha peternakan sapi yang sedang dijalankan. Termasuk di dalam isi materi adalah tahapan bagaimana membentuk sebuah kelompok dan bagaimana mengelolanya. Materi ini disusun dan sisampaikan oleh Amiril Mukmin, S.Pt., MP., M.Sc., dan Ertika Fitri Lisnanti, drh., M.Si. dari Program Studi PeternakanFakultas Pertanian UNISKA
Kediri. Materi selengkapnya terkait dengan pelatihan pertama dapat dilihat di "Kumpulan Materi Pelatihan" pada bagian "Pelatihan Pertama" yang dilampirkan dalam laporan kegiatan ini.

Berdasarkan hasil pemantauan saat penyampaian materi dan diskusi, ternyata beberapa peternak di Magetan sudah membentuk kelompok. namun demikian, kelompok yang sudah ada ini belum berbadan hukum dan kondisinya tidak aktif. kondisi lain yang lebih memprihatinkan, ada kelompok yang dibentuk hanya untuk mendapatkan bantuan dari pemerintah saja, sehingga ketika bantuan sudah diterimakan kelompok sudah tidak terurus lagi.

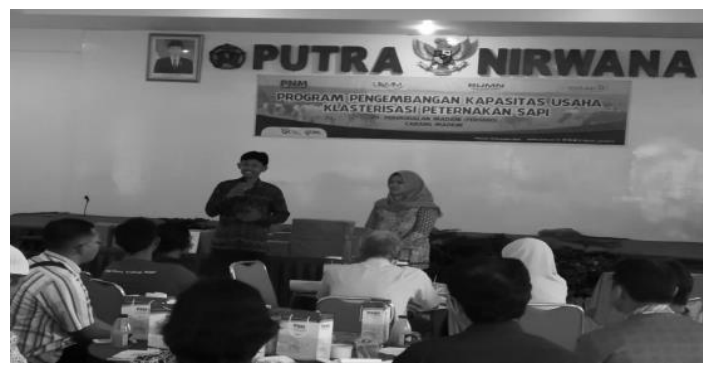

Gambar 8. Diskusi dalam pelatihan bersama.

Untuk membentuk kelompok ternak yang solid dan mampu meningkatkan kemakmuran peternak, keinginan berkelompok harus muncul dari diri peternak itu sendiri, pihak luar termasuk akademisi, pemodal, ataupun pemerintah hanya bisa memotivasi dan mendampingi saja. Untuk itu, pelatihan ini lebih ditekankan untuk memotivasi supaya para peternak tertarik untuk melakukan usaha secara berkelompok. Baru ketika keinginan ini sudah muncul, terbentuknya kelompok bisa diresmikan, dan apabila diperlukan terkait legalitasnya bisa diajukan untuk meiliki badan hukum. Tahapan-tahapan untuk membentuknya juga disampaikan dalam pelatihan ini.

Pelatihan pertama berjalan cukup lancar dengan dihadiri sekitar 60 peserta. Para peserta cukup antusias dalam 
menyimak pemaparan materi dan juga bertanya dalam sesi diskusi. Di akhir pelatihan dilakukan pengenalan profil PNM kepada seluruh peserta. Kegiatan apa saja yang bisa mengajukan permodalan, dimana bisa mengajukan permodalan, dan bagaimana prosedur pengajuannya juga disampaikan secara singkat oleh tim PNM Madiun. Harapannya, apabila ada peserta yang membutuhkan permodalan bisa langsung menghubungi kantor PNM terdekat.

Pelatihan kedua dilaksanakan pada hari Selasa, 08 Januari 2019 jam 09.00 di Ruang Pertemuan Putra Nirwana, PlaosanMagetan. Pelatihan ini mengangkat topik "Jago Bikin Pakan, Panduan Praktis Pembuatan Pakan Ternak Alternatif Untuk Ruminansia". Pakan merupakan faktor penting yang harus diperhatikan dalam usaha peternakan. Namun demikian masih banyak peternak, khususnya peternakan rakyat yang masih mengabaikan maslah pakan ini.

Pelatihan terkait dengan pakan ini difokuskan untuk mengoptimalkan potensi sumber pakan yang ada disekitar peternak. Pengawetan hijauan untuk menjaga kestabilan stoknya di musim kemarau atau untuk tujuan supaya peternak tidak harus merumput setiap hari juga disampaikan , bahkan dilanjutkan pendalaman dengan praktek. Apabila peternak sudah memiliki persediaan pakan, maka peternak akan memiliki waktu lebih untuk memikirkan

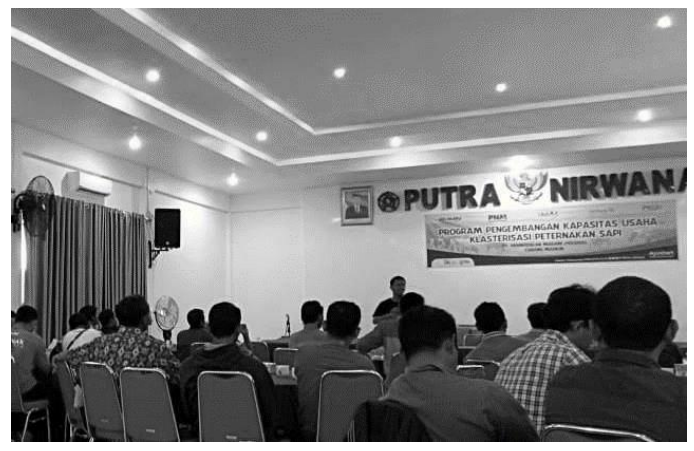

Gambar 9. Penyampaian materi pada pelatihan kedua strategi untuk meningkatkan kapasitas usahanya atau mengembangkan usaha di bidang yang lain.

Materi tentang pakan ini disusun dan sisampaikan oleh Muhammad Tanfidzul Khoiri dari Pusat Pelatihan Pertanian dan Pedesaan Swadaya (P4S) Lembaga Kajian dan Pengembangan Potensi Umat (LKP2U) Madiun. Materi selengkapnya terkait dengan pelatihan kedua dapat dilihat di "Kumpulan Materi Pelatihan" pada bagian "Pelatihan Kedua" yang dilampirkan dalam laporan kegiatan ini.

Peternak di Magetan kebanyakan masih mengandalkan hijauan sebagai pakan tunggal untuk ternaknya, sehingga sangat diperlukan usaha pengolahan atau pengawetan supaya peternak tidak setiap hari disibukkan dengan kegiatan merumput. Dengan usaha pengawetan, ketersediaan hijauan yang berlimpah di musim penghujan dapat diawetkan untuk persediaan di musim kemarau saat ketersediaan hijauan sedikit.

Pengawetan hijauan melalui silase adalah penerapan teknologi yang sangat sederhana dalam bidang peternakan. Namun demikian, ternyata banyak peternak yang kesulitan menerapkan karena belum memahami keunggulan dan tekniknya secara menyeluruh. Selain itu, hal lain yang menjadi penyebab kembali lagi adalah karena jumlah kepemilikan ternak yang masih sedikit sehingga penerapan teknologi ini dirasa kurang ekonomis dan peternak merasa masih mampu merumput setiap hari. Pola pikir ini yang perlu kita rubah. Peternak harur lebih visioner, harus punya target untuk mengembangkan kapasitas usahanya.

Pemateri dalam pelatihan kedua ini juga seorang praktisi, seorang peternak yang secara langsung terjun ke usaha peternakan. Kegiatan pelatihan kedua ini bisa dinilai berjalan lancar. Dengan metode penyampaian yang cukup santai dan ditambah dengan cerita tentang 
pengalaman-pengalaman dari pemateri dalam mengelola ternaknya, peserta yang berjumlah sekitar 70 orang terlihat cukup menikmati pelatihan ini. Beberapa pertanyaan juga diajukan oleh peserta selama sesi diskusi.

Setelah selesai penyampaian materi dan diskusi pelatihan kedua, tim PNM memberikan informasi tentang profil PNM, kiprah PNM dalam membantu permodalan usaha masyarakat, jenis usaha apa saja yang bisa mengajukan permodalan, dimana bisa mengajukan permodalan, dan bagaimana prosedur pengajuannya juga disampaikan secara singkat oleh tim PNM Madiun. Penyampaian materi ini dilakukan karena beberapa peserta yang hadir di pelatihan kedua ini adalah peserta baru. Harapannya, apabila ada peserta yang membutuhkan permodalan bisa langsung menghubungi kantor PNM terdekat.

Di akhir sesi, setelah istirahat untuk sholat dan makan, kegiatan dilanjutkan dengan praktek pembuatan pakan silase. Kegiatan ini ditujukan untuk memperdalam pemahaman peserta pelatihan dalam hal praktek pengawetan hijauan untuk pakan ternak. Praktek dilaksanakan di halaman parker Rumah Makan Putra Nirwana. Peralatan dan bahan sudah disiapkan panitia. Tim pemateri memperagakan teknik pembuatan silase dan peserta menyimak dengan seksama.

Pelatihan ketiga dilaksanakan di ruang pertemuan Putra Nirwana PlaosanMagetan pada hari Selasa, 15 Januari 2019 mulai pukul 14.00. Pada awalnya, pelatihan ketiga akan diisi dengan topik kesehatan ternak, namun berdasarkan hasil survey ternyata banyak juga peternak di Magetan yang melakukan kegiatan usaha sapi perah dan briding sapi potong. Kedua kegiatan tersebut didomonasi ternak betina dengan kendala yang sering dihadapi peternak berupa gangguan reproduksi, maka topik pada pelatihan ketiga ditambahkan materi tentang reproduksi. Judul yang diangkat adalah "Reproduksi dan Kesehatan Ternak".

Tujuan dari penyampaian pelatihan ketiga adalah untuk mengurai permasalahan yang dihadapi peternak terutama yang terkait dengan reproduksi dan kesehatan ternak. Harapannya, peternak mengetahui kondisi ternak yang sedang dipelihara, apabila sedang menghadapi kendala, peternak bisa memprediksi penyebabnya dengan akurat dan bisa menangani dengan tepat. Materi ini disusun dan sisampaikan oleh Ertika Fitri Lisnanti, drh., M.Si. Beliau adalah ahli reproduksi dan kesehatan ternak dari Program Studi Peternakan Fakultas Pertanian UNISKA Kediri. Materi selengkapnya terkait dengan pelatihan ketiga dapat dilihat di "Kumpulan Materi Pelatihan" pada bagian "Pelatihan Ketiga" yang dilampirkan dalam laporan kegiatan ini.

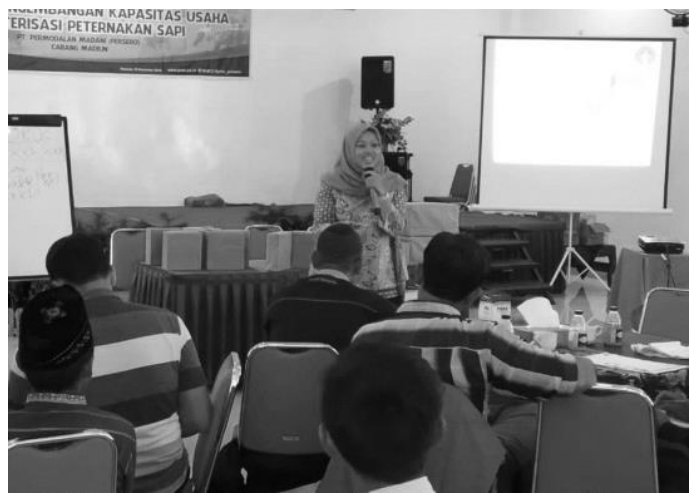

Gambar 10. Penyampaian materi dan diskusi pada pelatihan ketiga

Karena kegiatan dilaksanakan pada sore hari dan diprediksi akan membutuhkan waktu yang cukup panjang, maka sesi diskusi dan penyampaian materi digabung. Apabila peserta memiliki pertanyaan terkait topik yang sedang dibahas, peserta dipersilahkan langsung mengajukan pertanyaan.

Peserta yang berjumlah sekitar 80 orang cukup antusias mengikuti pelatihan 
ini. Beberapa pertanyaan diajukan oleh peserta secara bergantian dan langsung dijawab oleh pemateri sampai tuntas. Namun karena keterbatasan waktu, ada beberapa topik dari kesehatan ternak tidak dapat tersampaikan. Untuk mensikapi hal tersebut, pemateri sudah menyiapkan materi dengan pemaparan yang terperinci sehingga peserta bisa mempelajarinya sendiiri di rumah. Apabila ada pertanyaan terkait materi tersebut, peserta dipersilahkan menanyakannya atau konsultasi melalui SMS atau WA ke pemateri atau melaui grup WA yang telah dibentuk untuk media komunikasi bersama.

Dikarenakan ada peserta yang baru ikut di pelatihan ketigai, tim PNM memanfaatkan waktu yang singkat di akhir pelatihan untuk memberikan informasi tentang profil PNM, kiprah PNM dalam membantu permodalan usaha masyarakat, jenis usaha apa saja yang bisa mengajukan permodalan, dimana bisa mengajukan permodalan, dan bagaimana prosedur pengajuannya. Harapannya, apabila ada peserta yang membutuhkan permodalan bisa langsung menghubungi kantor PNM terdekat.

Pelatihan ke empat atau pelatihan terakhir dilaksanakan pada hari Kamis, 07 Pebruari 2019 mulai jam 9.00 pagi di ruang pertemuan Putra Nirwana PlaosanMagetan. Sesuai rencana awal, pelatihan terakhir ini mengangkat topik "Olahan Produk Peternakan Zaman Now dan Cooking Demo Olahan Sapi”. Penentuan topik ini ditujukan untuk memperkenalkan variasi produk olahan baru dari daging sapi kepada peserta pelatihan yang pada umumnya adalah peternak. Selesai mengikuti pelatihan terakhir ini diharapkan peternak akan lebih kreatif dalam dan menemukan variasi-variasi baru dari olehan produk ternak, khususnya daging.

Materi pelatihan terkait olahan ini disusun dan disiapkan oleh tim Ayo Start bersana tim juru masak dari rumah makan Putra Nirwana. Kegiatan pelatihan diawali dengan pemaparan karakter daging sapi yang berasal dari beberapa bagian tubuh yang berbeda. Yang perlu ditegaskan adalah bahwa daging yang berasal dari bagian tubuh yang berbeda juga memiliki karakter yang berbeda. Setelah menjelaskan terkait karakter daging, pelatihan dilanjutkan dengan demo memasak.

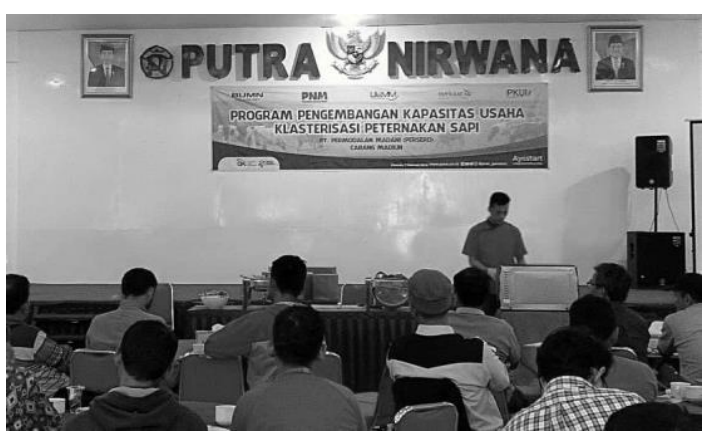

Gambar 11. Demo memasak pada pelatihan keempat

Kegiatan ini berjalan cukup lancar. Dengan dihadiri sekitar 60 peserta, semua peserta cukup antusias dalam mencicipi produk olahan hasil demo memasak. Berdasarkan hasil pengamatan pada waktu pelatihan, ada sedikit kekurangan dalam kegiatan pelatiahan terakhir ini. Kekurangan tersebut antara lain adalah: peserta tidak diberi resep atau detail cara membuat produk olahan tersebut; variasi olahan daging yang diperagakan hanya satu macam; dan yang terakhir kebanyakan peserta pelatihan yang seorang peternak merasa tidak cocok dengan cita rasa olahan daging yang diperagakan. Namun demikian, jika diambil dari sisi positifnya hal ini tidak menjadi masalah. Setelah mengikuti pelatihan ini, dengan dibekali pengetahuan tentang karakter daging, peserta bisa melakukan improvisasi untuk menghasilkan variasi olahan daging yang baru yang memiliki citarasa yang disukai peternak.

Kegiatan penutupan program dilaksanakan setelah pelatihan keempat. Kegiatan ini dilaksanakan 1 minggu lebih 
awal dari yang direncanakan. Secara resmi, program ditutup oleh bapak Muhamad Yusbar selaku kepala cabang PNM Madiun. Dalam sambutan penutupan, beliau mengucapkan terima kasih kepada semua pihak yang mendukung kelancaran program ini, khususnya para peserta yang selalu hadir di semua rangkaian acara pelatihan. Terakhir beliau mengingatkan apabila ada peserta yang membutuhkan permodalan bisa langsung menghubungi kantor PNM terdekat.

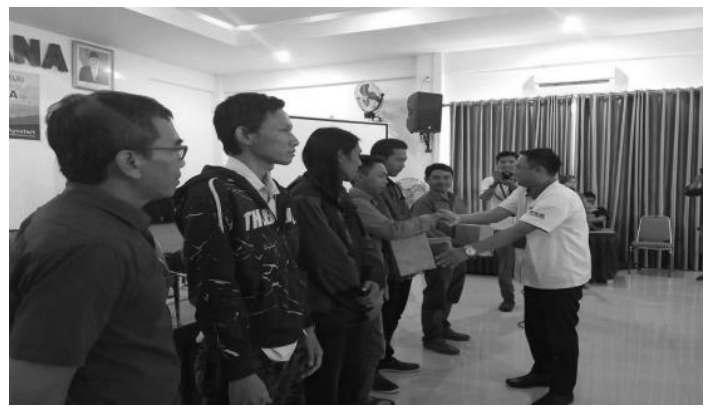

Gambar 12. Pembagian doorprize oleh kepala cabang PNM Madiun kepada peserta yang beruntung

Setelah penutupan acara, ada pengundian dan pembagian doorprize kepada para peserta yang beruntung. Sertifikat dan kaos sebagai kenangkenangan juga diberikan kepada seluruh peserta yang hadir di semua kegiatan pelatihan yang telah dilaksanakan.

\section{Penutup}

Program pendampingan secara resmi sudah ditutup pada tanggal 7 Pebruari 2019. Namun demikian, pendampingan usaha peternakan secara informal masih terus bisa dilanjutkan melalui komunikasi dengan media sosial. Panitia telah membentuk grup "PKU KLASTER USAHA SAPI" di WA. Peternak yang mengalami kendala dalam usaha peternakannya bisa melakukan diskusi dalam grup tersebut atau konsultasi secara langsung kepada pendamping melalui pesan pribadi.

\section{Simpulan}

Berdasarkan hasil kegiatan yang telah

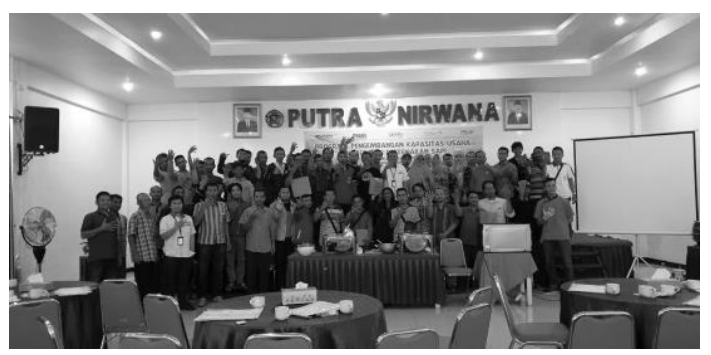

Gambar 13. Foto bersama acara penutupan

dilaksanakan, dapat disimpulkan bahwa: 1.Secara umum kegiatan ini berjalan lancar dengan peserta yang hadir tidak pernah kurang dari 60 orang, padahal dari yang diperkirakan di awal hanya sekitar 40-45 peserta; 2.Materi yang disampaikan sesuai dengan yang dibutuhkan oleh peternak sehingga peserta yang hadir cukup antusias dan selalu ada diskusi di setiap pelatihan; 3.Kegiatan pendampingan secara formal telah ditutup secara resmi, namun kegiatan pendampingan secara informal dan konsultasi masih terus bisa dilaksanakan melalui grup media sosial di whatsapp yang sudah dibentuk oleh panitia.

\section{Daftar Pustaka}

Nugroho, CP. 2008. Agribisnis Teknik Ruminansia. Departemen Pendidikan Nasional.

Sodiq, Akhmad \& Budiono, Machfudin. 2012. Produktivitas Sapi Potong pada Kelompok Tani Ternak di Pedesaan. Agripet, 12(1), 28-33. Retrieved from http://jurnal.unsyiah.ac.id/agripet/article/vie wFile/284/270

Toelihere R. Mozes. 1985. Fisiologi Reproduksi Pada Ternak. Penerbit Angkasa Bandung.

Usman Budi. 2006. Buku Ajar Dasar Ternak Perah, Departemen Peternakan Fakultas Pertanian, Universitas Sumatera Utara. 